\title{
Sistem Monitoring Debit Inflow untuk Operasi Harian Pembangkit PLTA Bakaru
}

\author{
La Ode Musa $^{1^{*}}$, Yiyin Klistafani ${ }^{2}$, dan Rudi Sumarwanto ${ }^{3}$ \\ 1,2,3 Jurusan Teknik Mesin, Politeknik Negeri Ujung Pandang, Makassar 90245, Indonesia \\ *laode_musa@poliupg.ac.id@poliupg.ac.id
}

\begin{abstract}
The high demand for electrical energy resources requires humans to make the best use of energy sources contained in nature. The use of renewable energy as a source of electrical energy is one of the efforts that must be increased, Indonesia has a large enough water potential that can be utilized as a source of electrical energy, the source of electrical energy derived from water energy has several problems, one of which is in maximizing the use of water in dams, good planning will maximize the use of water for generation. The purpose of this research is to create an inflow discharge monitoring system for the daily operation of the Bakaru hydropower plant. The data collection of this research was located in the Bakaru Hydroelectric Power Plant. Data obtained from daily recording data, Monthly reports and Business reports. The data collection of this research was carried out in realtime on the data of the Bakaru Hydroelectric Dam from January 2015 to December 2016, which was taken once every hour at the dam, namely dam elevation data, use of discharges, discharges of water entering the dam (Inflow) and dam gate runoff data. Inflow discharge monitoring system for daily operations helps operators in planning daily operating patterns based on inflow discharge and water usage used for generation. Daily operating pattern is one of the important factors to increase production results. The monitoring system can simulate for calculation of elevation, water holding time and inflow discharge. Based on the results of the study, it was found that the inflow discharge monitoring system for daily operations is very useful to optimize the operation of the Bakaru hydropower system, reducing the start stop range so that the equipment lifetime can be achieved as well as the Capacity factor (CF) can be increased.
\end{abstract}

Keyword: PLTA, Debit Inflow, Discharge, Capacity factor

\begin{abstract}
Abstrak : Tingginya kebutuhan akan sumber daya energi listrik menuntut manusia untuk memanfaatkan sumber energi yang terkandung di alam sebaik mungkin. Pemanfaatan energi terbarukan menjadi sumber energi listrik merupakan salah satu upaya yang harus di tingkatkan, Indonesia memiliki potensi air cukup besar yang bisa dimanfaatkan menjadi sumber energi listrik, sumber energi listrik yang berasal dari energi air mempunyai beberapa masalah salah satunya dalam memaksimalkan penggunaan air pada bendungan, perencanaan yang baik akan memaksimalkan penggunaan air untuk pembangkitan. Adapun tujuan dari penelitian adalah membuat sistem monitoring debit inflow untuk operasi harian pembangkit PLTA Bakaru. Pengambilan data penelitian ini berlokasi di PLTA Bakaru. Data diperoleh dari data pencatatan harian, laporan Bulanan dan laporan Pengusahaan. Pengambilan data penelitian ini dilakukan secara realtime pada data bendungan PLTA Bakaru mulai Januari tahun 2015 sampai dengan Desember 2016, yang diambil persetiap satu jam sekali pada bendungan yaitu data elevasi bendungan, pemakaian pembangkitan (discharge), debit air yang masuk ke bendungan (Inflow) serta data limpasan pintu bendungan. Sistem monitoring debit inflow untuk operasi harian membantu operator dalam perencanaan pola operasi harian berdasarkan debit inflow dan pemakaian air yang digunakan untuk pembangkitkan. Pola operasi harian merupakan salah satu faktor yang penting untuk meningkatkan hasil produksi. Sistem monitoring tersebut dapat mensimulasikan untuk perhitungan elevasi,waktu tampung air dan debit inflow. Berdasarkan hasil penelitian maka di dapatkan bahwa sistem monitoring debit inflow untuk operasi harian sangat berguna untuk megoptimalkan sistem pengoperasian PLTA bakaru, mengurangi range start stop sehingga lifetime peralatan dapat tercapai demikian pula Capacity factor (CF) dapat ditingkatkan.
\end{abstract}

Kata kunci : PLTA, Debit Inflow, Discharge, Capacity factor

\section{PENDAhUluan}

Pusat Listrik Tenaga air (PLTA) Bakaru merupakan pusat listrik tenaga air yang memiliki desain mesin poros tegak dengan tipe turbin Francis, dengan kapasitas 2 x 63 MW. PLTA Bakaru menjadi pembangkit yang sangat diharapkan keandalanya untuk menyuplai listrik ke sistem interkoneksi 150 KV Sulawesi Selatan dan Sulawesi Barat. Pengoperasian PLTA Bakaru sangat dipengaruhi oleh 
kondisi cuaca dan musim. Kondisi cuaca dan iklim di indonesia yang tidak menentu, mempengaruhi perubahan jumlah debit air masuk bendungan atau inflow bendungan.

Bendungan PLTA Bakaru memiliki masalah dari segi sedimentasi yang menyebabkan berkurangnya volume tampung air pada waduk PLTA Bakaru. Kapasitas penampungan waduk mencapai $6.920 .000 \mathrm{~m} 3$ dan kapasitas efektifnya mencapai 5.860.000 m3, akan tetapi kondisi saat ini kapasitas waduk hanya sekitar $800.000 \mathrm{~m} 3$ [1,2]Perubahan volume waduk berdampak pada level minimum dan maksimum elevasi bendungan. Kondisi elevasi waduk yang terlalu rendah menyebabkan sedimen masuk ke dalam turbin, sehingga mengakibatkan abrasi pada peralatan pembangkit. Pola pengoperasian PLTA Bakaru menjaga kesetabilan elevasi di batas minimum 614,00 mdpl dan maksimum 615,53 mdpl, sesuai dengan rencana operasi harian yang telah ditetapkan $[1,2]$. Elevasi tersebut dapat dikontrol dengan 8 buah pintu pelimpah atau debit limpasan yang berbeda.

Ketika musim kering (no flood season) debit inflow $>30 \mathrm{~m}^{3} /$ detik , PLTA Bakaru hanya mampu beroperasi dibeban maksimal pada saat beban puncak (peak load). Setelah lewat beban puncak PLTA Bakaru beroperasi dibeban minim atau beroperasi satu unit untuk menampung air sampai elevasi maksimal. Operator control room (ruang kontrol) hanya memonitoring kondisi inflow dan elevasi secara realtime setiap 1 jam sekali, sehingga sering menyebabkan naik turun beban bahkan start stop unit untuk mempertahankan kondisi elevasi bendungan maksimal. Pola operasi demikian sangat tidak efektif, seringnya naik turun beban dan start stop unit berakitbat tidak maksimalnya jam operasi unit serta produksi yang dibangkitkan. Flood season (musim basah) debit inflow $<45 \mathrm{~m}^{3} /$ detik, PLTA Bakaru mampu beroperasi dibeban maksimal pada waktu lewat beban puncak maupun pada saat beban puncak. Operator control room (ruang kontrol) hanya memonitoring perubahan elevasi dengan melakukan pengoperasian pintu pelimpah atau limpasan untuk menyetabilkan elevasi. Hal tersebut terjadi karena tidak adanya simulasi perhitungan sistem monitoring debit inflow dan perubahan elevasi untuk operasi harian.

Berdasarkan dengan latar belakang permasalah tersebut, pada penelitian ini akan mengevaluasi sistem monitoring debit inflow untuk operasi harian pembangkit berdasarkan debit inflow yang masuk pada bendungan PLTA Bakaru, sehingga pola operasi harian pembangkit dapat dioptimalkan dengan metode perbandingan debit inflow dan kondisi pemakain air untuk operasi harian pembangkit. Penelitian ini diharapkan dapat menjadikan suatu solusi dalam mengoptimalkan pola operasian pembangkit yang efektif dan efesien.

\section{METODE PENELITIAN}

Adapun metode penelitian yang dilakukan adalah:

\section{A. Tempat dan Waktu Penelitian}

Metode Pengambilan data penelitian ini berlokasi di PLTA Bakaru. Data diperoleh dari data pencatatan harian, laporan Bulanan dan laporan Pengusahaan. Pengambilan data penelitian ini dilakukan secara realtime pada data bendungan PLTA Bakaru mulai Januari tahun 2015 sampai dengan Desember 2016, yang diambil persetiap satu jam sekali pada bendungan yaitu data elevasi bendungan, pemakaian pembangkitan (discharge), debit air yang masuk ke bendungan (Inflow) serta data limpasan pintu bendungan.

\section{B. Parameter yang digunakan dalam penelitian}

Parameter yang digunakan untuk Pengambilan data secara realtime setiap satu jam sekali pada bendungan yaitu data elevasi bendungan, pemakaian pembangkitan (discharge), debit Inflow yang masuk ke bendungan.

\section{Teknik pengumpulan data}

Proses pengambil data pada penelitian dilakukan setelah mendapatkan izin dari manajer unit PLTA Bakaru. Pengambilan data didapatkan dari bagian operasi. Data-data pencatatan ruang kontrol PLTA Bakaru, dalam bentuk data rekam digital dan data cetak rekaman dalam kurun waktu 2015 sampai dengan 2016. Setelah mendapatkan data rekam kemudian dilakukan seleksi data yang dibutukan untuk keperluan penelitian. 
72 Muas M, Syaharuddin R, Arwin S, Alfian N. Perancangan Belt Konveyor Kapasitas 25 TPH (Studi Kasus : PT. Bumi Mineral Sulawesi)

\section{HASIL DAN PEMBAHASAN}

Adapun hasil perhitungan dan pembahasan penelitian yang dilakukan adalah:

\section{A. Data Pengamatan}

Pengambilan data pengamatan dilakukan dengan menggunakan data pada kurun waktu bulan Januari 2015 sampai dengan bulan Desember 2016. Hal ini dikarenakan di dalam kurun waktu tersebut sudah mencakup dua siklus perubahan musim, yaitu dari musim hujan sampai musim kemarau. atau dengan kata lain data yang akan diperoleh dapat memperlihatkan fluktuasi angka debit inflow dan pemakaian air untuk pembangkitan, yaitu pada angka tertinggi dan terendah. Berikut data rata-rata pencatatan operasi harian PLTA Bakaru Januari 2015 - Desember 2016, dapat dilihat pada Tabel 1, debit inflow dan pemakaian air pembangkitan PLTA Bakaru.

Tabel 1. Data rata-rata pencatatan operasi harian PLTA Bakaru Januari 2015 - Desember 2016

\begin{tabular}{|c|c|c|c|c|c|c|c|c|c|c|c|}
\hline \multirow[b]{2}{*}{ No } & \multirow[b]{2}{*}{ Bulan } & \multicolumn{5}{|c|}{2015} & \multicolumn{5}{|c|}{2016} \\
\hline & & $\begin{array}{l}\text { Beban } \\
\text { (MW) }\end{array}$ & \begin{tabular}{|c|} 
Discharge \\
$\left(\mathrm{m}^{3} / \mathrm{s}\right)$
\end{tabular} & \begin{tabular}{|c|}
$\operatorname{limpasan}$ \\
$\left(\mathrm{m}^{3} / \mathrm{s}\right)$
\end{tabular} & $\begin{array}{l}\text { Inflow } \\
\left(\mathrm{m}^{3} / \mathrm{s}\right)\end{array}$ & \begin{tabular}{|l|} 
Elevasi \\
(m.dpl)
\end{tabular} & $\begin{array}{l}\text { Beban } \\
\left(\mathrm{m}^{3} / \mathrm{s}\right)\end{array}$ & $\begin{array}{c}\text { Discharge } \\
\left(\mathrm{m}^{3} / \mathrm{s}\right)\end{array}$ & \begin{tabular}{|c|}
$\operatorname{limpasan}$ \\
$\left(\mathrm{m}^{3} / \mathrm{s}\right)$
\end{tabular} & $\begin{array}{l}\text { Inflow } \\
\left(\mathrm{m}^{3} / \mathrm{s}\right)\end{array}$ & $\begin{array}{l}\text { Elevasi } \\
\text { (m.dpl) }\end{array}$ \\
\hline 1 & Januari & 104 & 37,20 & 8,70 & 45,83 & 615,36 & 74 & 27,75 & 4,35 & 32,51 & 615,30 \\
\hline 2 & Februari & 91 & 31,98 & 25,81 & 57,97 & 615,02 & 114 & 40,79 & 22,58 & 63,33 & 615,42 \\
\hline 3 & Maret & 114 & 40,30 & 23,01 & 64,97 & 615,42 & 124 & 44,00 & 33,39 & 77,29 & 615,44 \\
\hline 4 & April & 126 & 43,50 & 58,93 & 101,48 & 615,49 & 121 & 42,75 & 86,19 & 128,77 & 615,34 \\
\hline 5 & Mei & 125 & 43,26 & 24,53 & 67,83 & 615,48 & 126 & 44,51 & 63,91 & 108,54 & 615,43 \\
\hline 6 & Juni & 115 & 43,25 & 24,95 & 68,26 & 615,47 & 126 & 44,50 & 39,18 & 83,72 & 615,48 \\
\hline 7 & Juli & 69 & 27,20 & 0,00 & 31,26 & 615,27 & 124 & 43,78 & 19,16 & 62,94 & 615,48 \\
\hline 8 & Agustus & 51 & 19,12 & 0,00 & 18,76 & 615,19 & 108 & 38,78 & 5,54 & 45,13 & 615,40 \\
\hline 9 & September & 35 & 13,33 & 0,00 & 13,69 & 615,19 & 105 & 38,42 & 13,89 & 52,54 & 615,42 \\
\hline 10 & Oktober & 35 & 13,24 & 0,00 & 13,61 & 615,19 & 126 & 44,35 & 63,38 & 107,79 & 615,43 \\
\hline 11 & November & 47 & 17,94 & 0,22 & 18,91 & 615,28 & 105 & 37,14 & 64,64 & 101,21 & 615,35 \\
\hline 12 & Desember & 66 & 25,05 & 0,54 & 25,83 & 615,27 & 124 & 43,85 & 25,93 & \begin{tabular}{|l|l}
70,03 \\
\end{tabular} & 615,45 \\
\hline
\end{tabular}

Data Tabel 1 menujukan bahwa pada bulan Juli sampai dengan Desember 2015 terjadi musim kemarau, debit inflow rata-rata $>30 \mathrm{~m}^{3} / \mathrm{s}$, sehingga pola pengoperasian tidak mencapai nilai maksimum. Musim hujan terjadi pada bulan Januari sampai dengan Desember 2016 dengan debit inflow rata-rata 44,5 m³ s sehingga pengoperasian PLTA Bakaru menjadi maksimum yaitu $126 \mathrm{MW}$. Berdasarkan data tersebut serta perbedaan musim, pola pengoperasian PLTA Bakaru disesuaikan dengan debit inflow dari Waduk.

\section{B. Analisa Data}

\section{Review pola operasi harian PLTA Bakaru}

Pola pengoperasian turbin serta pencapaian kinerja pembangkit merupakan program yang selalu sejalan di suatu sistim pembangkit, seperti halnya pada Pembangkit Listrik Tenaga Air (PLTA), namun dengan kondisi debit inflow, pemakaian air yang fluktuatif Waduk/Bendungan tujuan tunggal (single purpose), menjadi salah satu kendala dalam mencapai hal tersebut. Sistem monitoring debit inflow untuk operasi harian dibutuhkan untuk mencapai optimalisasi pengoperasian turbin.

\section{Hubungan debit inflow waduk terhadap pola operari harian PLTA Bakaru}

Debit inflow yang masuk kebendungan menjaga kesetabilan Elevasi Reservoir dibatasi diantara nilai minimal dan maksimal yang diperbolehkan, nilai elevasi maksimal terkait dengan kapasitas maksimum air yang dapat ditampung sedangkan elevasi minimal dibatasi terkait operasi PLTA agar tetap stabil [3]. Perubahan debit inflow PLTA Bakaru sesuai dengan perhitungan pola operasi pembebanan, kebutuhan pemakaian air untuk pembangkitan atas dasar kondisi elevasi Waduk PLTA Bakaru. Hubungan antara debit inflow dengan Pola operasi pembebanan adalah berbanding lurus, seperti yang ditunjukkan pada Gambar 1. 


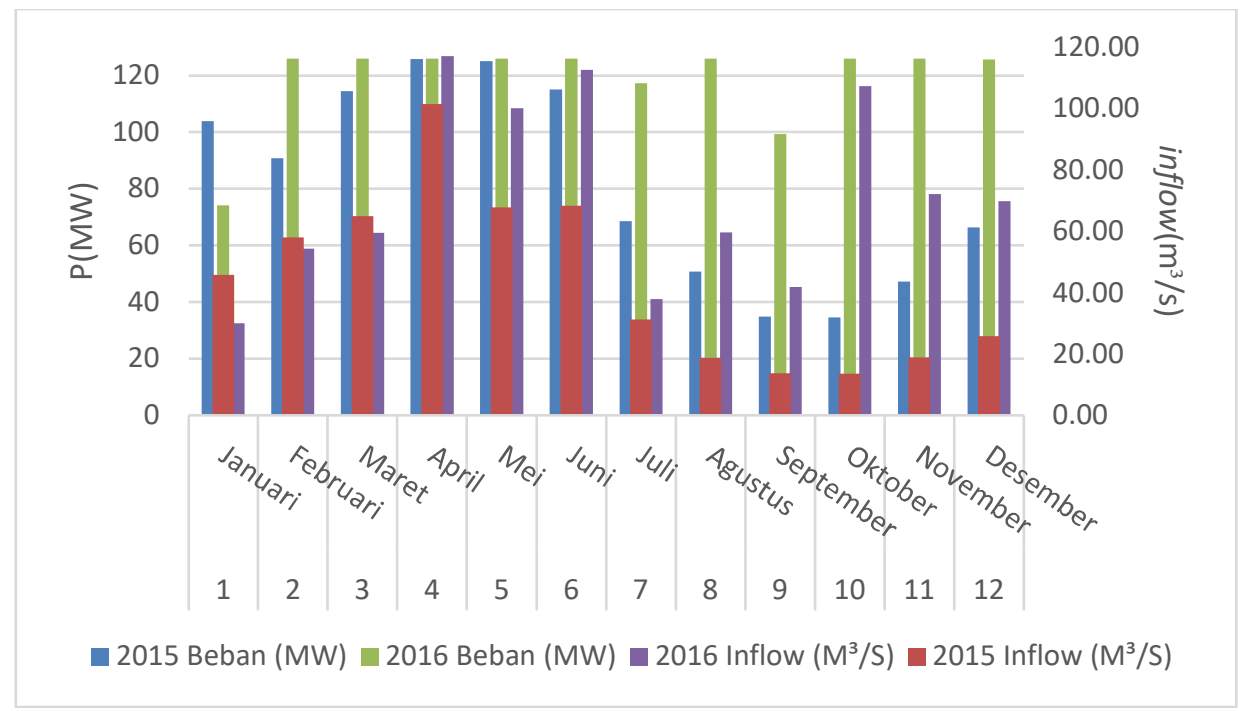

Gambar 1. Grafik pola pembebanan terhadap inflow

Pengaturan beban PLTA Bakaru berdasarkan perubahan debit inflow, elevasi Waduk, turut mempengaruhi pola operasi harian PLTA Bakaru. Hal ini dikarenakan operasional unit pembangkit yang ada harus disesuaikan pula dengan debit inflow yang masuk ke bendungan. Penurunan debit inflow waduk mengkibatkan masing-masing unit pembangkit mengharuskan turun beban agar elevasi tetap stabil. Menurut Cateni, [4] "Tingkat kinerja dari Hydro Power Plant ditandai dengan rugi-rugi pada turbin, sementara jumlah kerugian yang terjadi bervariasi akibat variasi dari salah satu atau kedua-duanya yaitu head dan discharge.

\section{Presentase debit Inflow}

Debit inflow yang masuk ke Waduk PLTA Bakaru kemudian disalurkan ke pembangkit untuk pengoperasian masing-masing unit, yang mengacu kepada batas beban minimum $40 \%$ dari daya netto $[1,2]$. Adanya batasan tersebut, maka dibuatlah pola operasi unit pembangkit berdasarkan debit inflow. Grafik data inflow 2015 sampai dengan 2016 dapat di lihat pada Gambar 2.

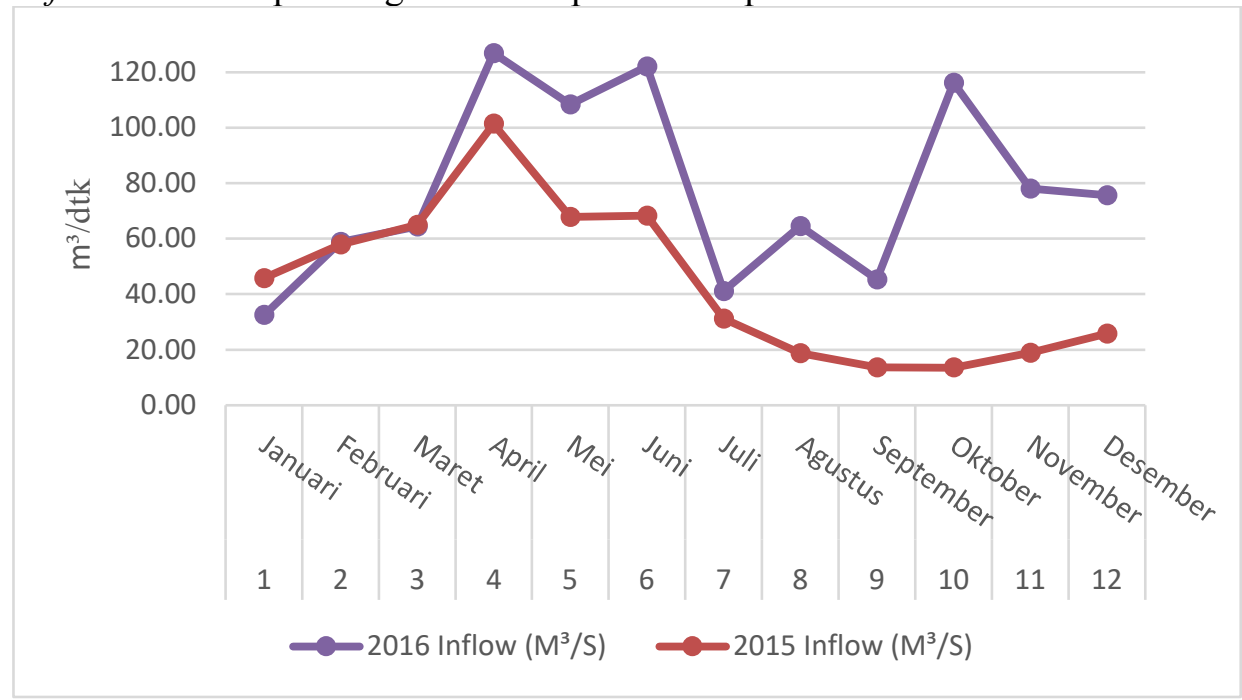

Gambar 2. Grafik data inflow 2015 sampai dengan 2016 
Gambar 2 menunujukan nilai debit inflow minimum yaitu 13,61 $\mathrm{m}^{3} / \mathrm{s}$ dibulan Sepetember dan Oktober 2015, 2 unit standby pada saat lewat beban puncak untuk menampung air hingga elevasi maksimal. Bulan juli sampai dengan November terjadi penurunan debit inflow yang mengakibatkan dilakukan pengalihan pengoperasian unit, yaitu dari unit 2 menjadi unit 1 . Pengoperasian 2 unit dapat dioperasikan pada saat debit inflow sudah mencapai 25 sampai dengan $35 \mathrm{~m}^{3} / \mathrm{s}$ yaitu pada saat pertengahan bulan Desember 2015, atau saat memasuki awal musim hujan. Perubahan debit inflow maksimum terjadi pada bulan Januari sampai dengan Desember 2016, unit 1 dan 2 mampu dioperasikan maksimum dengan persentase debit inflow lebih dari $35 \mathrm{~m}^{3} / \mathrm{s}$. Penurunan debit inflow dari Waduk Bakaru dengan sendirinya mengakibatkan perubahan pola pembebanan pola operasi harian masing-masing unit di PLTA Bakaru, yang akan berdampak pada tidak maksimal produksi unit pembangkit.

\section{Presentase pemakaian air (discharge)}

Pemakaian air yang disalurkan dari Waduk Bakaru ke pembangkit kemudian akan dibagi untuk pengoperasian masing-masing unit, yang mengacu kepada batas minimum debit air pemakaian air setiap unit. Adanya batasan tersebut, maka dibuatlah pola operasi unit pembangkit berdasarkan pemakaian air unit. Berdasarkan data design pemakaian air maksimal untuk 2 unit adalah $45 \mathrm{~m}^{3} / \mathrm{s}$ pembebanan $126 \mathrm{MW}$, maka dapat dibuat tabel data beban dan pemakaian air di minimum sampai dengan maksimum menggunakan persamaan kontinunitas. Data pemakaian air berdasarkan pembebanan dapat dilihat pada Tabel 2.

Tabel 2. Pemakaian air berdasarkan pembebanan

\begin{tabular}{|c|c|c|c|c|c|c|c|c|c|c|c|c|c|c|c|c|c|c|c|}
\hline \multirow{3}{*}{$\begin{array}{c}\text { BEBAN } \\
63 \\
\text { BEBAN }\end{array}$} & \multicolumn{3}{|c|}{ DISCHARGE } & \multirow{2}{*}{\multicolumn{16}{|c|}{ HU1 }} \\
\hline & \multicolumn{3}{|c|}{22,5} & & & & & & & & & & & & & & & & \\
\hline & 27 & 29 & 31 & 33 & 35 & 37 & 39 & 41 & 43 & 45 & 47 & 49 & 51 & 53 & 55 & 57 & 59 & 61 & 63 \\
\hline DISCHARGE & 12,5 & 13,1 & 13,6 & 14,2 & 14,7 & 15,3 & 15,9 & 16,4 & 17 & 17,5 & 18,1 & 18,7 & 19,2 & 19,8 & 20,3 & 20,9 & 21,5 & 22 & 22,5 \\
\hline BEBAN & \multicolumn{3}{|c|}{ DISCHARGE } & \multirow{2}{*}{\multicolumn{16}{|c|}{ HU2 }} \\
\hline 60 & \multicolumn{3}{|c|}{20,7} & & & & & & & & & & & & & & & & \\
\hline BEBAN & 27 & 29 & 31 & 33 & 35 & 37 & 39 & 41 & 43 & 45 & 47 & 49 & 51 & 53 & 55 & 57 & 59 & 61 & 63 \\
\hline DISCHARGE & 11,5 & 12,1 & 12,6 & 13,2 & 13,7 & 14,3 & 14,9 & 15,4 & 16 & 16,5 & 17,1 & 17,7 & 18,2 & 18,8 & 19,3 & 19,9 & 20,5 & 21 & 22 \\
\hline \multicolumn{20}{|l|}{ TOTAL } \\
\hline BEBAN & \multicolumn{3}{|c|}{ DISCHARGE } & & & & & & & & & & & & & & & & \\
\hline 123 & \multicolumn{3}{|c|}{43,2} & & & & & & & & & & & & & & & & \\
\hline
\end{tabular}

Berdasarkan data Tabel 2. terdapat kolom beban dan kolom pemakaian (discharge). Mengetahui pemakaian air berdasarkan beban dengan cara memasukan nilai pada kolom beban unit 1 dan unit 2 maka jumlah pemakaian air pada tersebut dapat diketahui. Total pemakaian air pada beban minimum 2 unit yaitu $24 \mathrm{~m}^{3} / \mathrm{s}$ sedangkan pada beban maksimum 2 unit yaitu $45 \mathrm{~m} / \mathrm{s}$. Nilai pemakaian air dapat menentukan pola operasi unit, ketika debit inflow kurang dari $30 \mathrm{~m}^{3} / \mathrm{s}$ maka unit hanya beroperasi 1 unit untuk menampung air hingga elevasi maksimal. Rencana pola operasi harian berdasarkan pemakaian air, dapat dijadikan dasar untuk membuat ROH (Rencana Operasi Harian) neraca beban. Seperti yang terlihat pada Tabel 4.2 beban minimum PLTA Bakaru setiap unit sebesar $27 \mathrm{MW}$, sedangkan beban maksimum setiap unit yaitu $63 \mathrm{MW}$.

\section{Perhitungan Inflow}

Pada perhitungan inflow melakukan pengolahan data yang telah dikumpulkan tersebut sesuai dengan karakteristik yang ada seperti pengolahan data debit inflow yang masuk ke waduk dan pembacaan volume tampungan waduk berdasarkan ketinggian elevasi (m.dpl). Rumus formula yang 
digunakan pada saat inflow kurang dari $100 \mathrm{~m}^{3} /$ detik, inflow didapatkan dari delta atau selisih pemakaian pembangkitan (discharge) dan limpasan persamaam (2.2) sebagai berikut :

Dimana :

$$
Q i=\frac{Q g_{1}+Q g_{2}}{2}+\frac{Q s_{1}+Q s_{2}}{2}+\frac{V_{2}-V_{1}}{3600 x t}
$$

Qi = inflow yang masuk pada bendungan $\left(\mathrm{m}^{3} / \mathrm{s}\right)$

$\mathrm{Qg}_{1}=$ outflow yang digunakan untuk pembangkitan jam sebelumnya $\left(\mathrm{m}^{3} / \mathrm{s}\right)$

$\mathrm{Qg}_{2}=$ outflow yang digunakan untuk pembangkitan jam sekarang $\left(\mathrm{m}^{3} / \mathrm{s}\right)$

$\mathrm{Qs}_{1}=$ limpasan pada jam sebelumnya $\left(\mathrm{m}^{3} / \mathrm{s}\right)$

$\mathrm{Qs}_{2}=$ limpasan pada jam sekarang $\left(\mathrm{m}^{3} / \mathrm{s}\right)$

$\mathrm{t} \quad=$ interval waktu observasi (detik)

$\mathrm{V}_{1}=$ volume bendungan pada jam sebelumnya $\left(\mathrm{m}^{3} / \mathrm{s}\right)$

$\mathrm{V}_{2}=$ volume bendungan pada jam sekarang $\left(\mathrm{m}^{3} / \mathrm{s}\right)$

Setelah melakukan pengolahan data dengan mengunakan debit inflow historis, pemakaian air, volume waduk, waktu interval secara tetap,pengolahan data bertujuan untuk melakukan simulasi sistem monitoring debit inflow untuk operasi harian pembangkit.

\section{Simulasi perhitungan elevasi}

Dalam situasi atau analisa perilaku operasi waduk bertujuan untuk mengetahui perubahan kapasitas tampungan waduk. Persamaan yang digunakan adalah kontinuitas tampungan (mass storage equation) yang memberi hubungan antara masukan, keluaran dan perubahan tampungan.

Persamaan secara matematika dinyatakan, sebagai berikut [5]:

$\mathrm{St}+1=\mathrm{St}+\mathrm{Qt}-\mathrm{Dt}-\mathrm{Et}-\mathrm{Lt}$

dengan:

$$
\begin{array}{ll}
\mathrm{St} & =\text { tampungan waduk pada awal interval waktu } \\
\mathrm{St}+1 & =\text { tampungan waktu pada akhir interval waktu } \\
\mathrm{Qt} & =\text { aliran masuk selama interval waktu t } \\
\mathrm{Dt} & =\text { lepasan air selama interval waktu } \mathrm{t} \\
\mathrm{Et} & =\text { evaporasi selama interval waktu t } \\
\mathrm{Lt} & =\text { kehilangan-kehilangan air lain dari waduk selama interval }
\end{array}
$$

waktu t, mempunyai harga yang kecil dan dapat diabaikan

\section{Simulasi perhitungan waktu tampung air}

Penelusuran banjir dengan cara Muskingum berlaku dalam kondisi:

1. Tidak ada anak sungai yang masuk ke dalam bagian memanjang palung sungai yang ditinjau.

2. Penambahan atau kehilangan air oleh curah hujan, aliran masuk atau keluar air tanah dan evaporasi, kesemuanya ini diabaikan.

Persamaan kontinuitas yang umum dipakai dalam penelusuran banjir adalah:

$I-Q=\frac{\mathrm{ds}}{\mathrm{dt}}$.

dimana:

I = debit yang masuk ke permulaan bagian memanjang palung sungai

$\left(\mathrm{m}^{3} / \mathrm{dt}\right)$

$\mathrm{Q}=$ debit yang keluar dari akhir bagian memanjang palung sungai $\left(\mathrm{m}^{3} / \mathrm{dt}\right)$

ds = besarnya tampungan (storage) $\left(\mathrm{m}^{3}\right)$

$\mathrm{dt}=$ periode penelusuran $(\mathrm{jam})$

\section{Sistem monitoring debit inflow operasi harian}

Merupakan suatu form perhitungan dengan menggunakan formula Microsoft excel yang digunakan untuk mengestimasikan pembebanan berdasarakan pemakaian air (discharge), sistem monitoring debit inflow operasi harian ini membantu operator dalam pola pengoperasian pembangkit, operator bisa 
76 Muas M, Syaharuddin R, Arwin S, Alfian N. Perancangan Belt Konveyor Kapasitas 25 TPH (Studi Kasus : PT. Bumi Mineral Sulawesi)

mengestimasi pembebanan dengan debit inflow air yang masuk ke bendungan, sehingga pola operasi harian dapat mengoptimalkan proses pembangkitan. Form sistem monitoring debit inflow dapat ditunjukan pada Tabel 3 .

\begin{tabular}{|c|c|c|c|c|c|}
\hline \multicolumn{6}{|c|}{ SISTEM MONITORING DEBIT INFLOW UNTUK OPERASI HARIAN } \\
\hline \multicolumn{3}{|c|}{ PERHITUNGAN ELEVASI } & \multicolumn{3}{|c|}{ PERHITUNGAN WAKTU } \\
\hline DISCHARGE $\left(\mathrm{m}^{3} / \mathrm{dt}\right)$ & INFLOW $\left(\mathrm{m}^{3} / \mathrm{dt}\right)$ & WAKTU (jam) & ELEVASI & m.dpl) & $\operatorname{VOLUME}\left(\mathrm{m}^{3}\right)$ \\
\hline 24 & 23,14 & 1 & SEKARANG & 615,29 & 747447 \\
\hline \multicolumn{2}{|c|}{ ELEVASI } & VOLUME & YANG DIINGINKAN & 615,5 & 892201 \\
\hline SEKARANG & 614,96 & 573172 & DISCHARGE $\left(\mathrm{m}^{3} / \mathrm{dt}\right)$ & INFLOW $\left(\mathrm{m}^{3} / \mathrm{dt}\right)$ & WAKTU (jam) \\
\hline SELANJUTNYA & 614,96 & 570076 & 0 & 14,23 & 3 \\
\hline & & 573172 & & & \\
\hline \multicolumn{6}{|c|}{ PERHITUNGAN INFLOW } \\
\hline \multicolumn{2}{|c|}{ ELEVASI (m.dpl) } & VOLUME $\left(\mathrm{m}^{3}\right)$ & & & \\
\hline SEBELUM & 615,49 & 884861 & & & \\
\hline SEKARANG & 615,35 & 782133 & & & \\
\hline DISCHARGE $\left(\mathrm{m}^{3} / \mathrm{dt}\right)$ & INFLOW SEBELUM $\left(\mathrm{m}^{3} / \mathrm{dt}\right)$ & INFLOW $\left(\mathrm{m}^{3} / \mathrm{dt}\right)$ & & & \\
\hline 44 & 31,35 & 21,91 & & & \\
\hline
\end{tabular}

Gambar 3. Form Sistem Monitoring Debit Inflow

Untuk mengunakan form sistem monitoring terdapat 3 macam perhitungan yaitu :

\section{a. Perhitungan elevasi}

Perhitungan elevasi berfungsi untuk mengetahui elevasi selanjutnya dengan kondisi pada saat ini. Penggunaannya dengan cara menginput data kolom discharge, inflow, waktu yang kita inginkan, serta elevasi sekarang. Hasil inputan data tersebut, dapat diperoleh perhintungan pada kolom hasil. Kolom hasil tersebut untuk mengetahui elevasi selanjutnya kita hanya mengubah nilai volume yang mendekati dari hasil perhitungan maka pada elevasi selanjutnya akan didapatkan nilainya.

\section{b. Untuk perhitungan waktu}

Perhitungan waktu berfungsi untuk mengetahui waktu yang diperlukan untuk menuju elevasi yang di inginkan. Penggunaannya dengan cara menginput pada kolom elevasi sekarang, evelasi yang di inginkan, discharge, inflow kemudian enter maka akan muncul nilai waktu.

\section{c. Perhitungan Inflow}

Perhitungan inflow berfungsi untuk mengetahui inflow saat ini. Penggunaannya dengan cara menginput pada kolom elevasi sebelumnya, elevasi sekarang, discharge, inflow sebelumnya kemudian enter maka akan muncul nilai inflow saat ini. 


\section{Pengujian}

Pengujian sistem monitoring debit inflow operasi harian dilakukan dengan cara membandingkan hasil perhitungan dengan data pencatatan harian pada Tabel 4.3 dengan data pengujian pada Tabel 4 .

Tabel 4. Data pencatata harian

\begin{tabular}{|c|c|c|c|c|c|c|c|}
\hline \multicolumn{8}{|c|}{ DATA BENDUNGAN PLTA BAKARU } \\
\hline \multirow{3}{*}{ NO } & \multirow[b]{2}{*}{ BEBAN } & \multirow[b]{2}{*}{ DISCH } & \multirow[b]{2}{*}{ LIMPAS } & \multirow[b]{2}{*}{ INFLOW } & \multicolumn{3}{|c|}{ ELEVASI } \\
\hline & & & & & DAM & $\begin{array}{c}\text { SURGE } \\
\text { TANK }\end{array}$ & $\begin{array}{l}\text { TAIL } \\
\text { RACE }\end{array}$ \\
\hline & ( MW ) & $\left(\mathrm{m}^{3} / \mathrm{dtk}\right)$ & $\left(\mathrm{m}^{3} / \mathrm{dtk}\right)$ & $\left(\mathrm{m}^{3} / \mathrm{dtk}\right)$ & ( m.dpl) & $(\mathrm{m})$ & $(\mathbf{m})$ \\
\hline 1 & 126,0 & 43,5 & 0 & 45.01 & 615,20 & UNDEF & 278,97 \\
\hline 2 & 121,0 & 42,5 & 0 & 44.50 & 615,21 & UNDEF & 278,95 \\
\hline 3 & 90,0 & 33,5 & 0 & 51,11 & 615,32 & UNDEF & 278,70 \\
\hline 4 & 61,0 & 25,8 & 0 & 57.20 & 615,48 & UNDEF & 278,48 \\
\hline 5 & 64,0 & 26,4 & 0 & 59,40 & 615,53 & UNDEF & 278,51 \\
\hline
\end{tabular}

Tabel 5. Data pengujian sistem monitoring debit inflow

\begin{tabular}{|c|c|c|c|c|c|c|c|}
\hline \multicolumn{8}{|c|}{ DATA BENDUNGAN PLTA BAKARU } \\
\hline \multirow{3}{*}{ NO } & \multirow[b]{2}{*}{ BEBAN } & \multirow[b]{2}{*}{ DISCH } & \multirow[b]{2}{*}{ LIMPAS } & \multirow[b]{2}{*}{ INFLOW } & \multicolumn{3}{|c|}{ ELEVASI } \\
\hline & & & & & DAM & $\begin{array}{l}\text { SURGE } \\
\text { TANK }\end{array}$ & $\begin{array}{l}\text { TAIL } \\
\text { RACE }\end{array}$ \\
\hline & ( MW ) & $\left(\mathrm{m}^{3} / \mathrm{dtk}\right)$ & $\left(\mathrm{m}^{3} / \mathrm{dtk}\right)$ & $\left(\mathrm{m}^{3} / \mathrm{dtk}\right)$ & (m.dpl) & $(\mathrm{m})$ & $(\mathrm{m})$ \\
\hline 1 & 126,0 & 43,5 & 0 & 45.01 & 615,20 & UNDEF & 278,97 \\
\hline 2 & 121,0 & 42,5 & 0 & 44.49 & 615,21 & UNDEF & 278,95 \\
\hline 3 & 90,0 & 33,5 & 0 & 51,10 & 615,32 & UNDEF & 278,70 \\
\hline 4 & 61,0 & 25,8 & 0 & 57.20 & 615,48 & UNDEF & 278,48 \\
\hline 5 & 64,0 & 26,4 & 0 & 59,40 & 615,53 & UNDEF & 278,51 \\
\hline
\end{tabular}

\section{Capacity Factor (CF)}

Capacity Factor atau Faktor Kapasitas suatu unit atau satuan pembangkit adalah perbandingan antara jumlah produksi listrik selama periode operasi terhadap jumlah produksi terpasang selama 1 (satu) periode (PT PLN (Persero) No. PLN/DKP-IKP/2007-01). Atau dengan kata lain kemampuan suatu unit pembangkit membangkitkan daya listrik sesuai dengan kapasitas terpasang dalam satu kurun waktu/periode (1 tahun), yang dinyatakan dalam satuan persen.

Berikut hasil analisa data pengamatan terhadap Capacity Factor masing-masing unit PLTA Bakaru, dengan mengambil sampel data produksi pada bulan Januari 2015.

Unit 1:

Produksi Listrik Bruto $=38086 \mathrm{MWh}$

Kapasitas Terpasang $=63 \mathrm{MW}$

Periode $=726 \mathrm{Jam}$

Sehingga:

$$
\begin{aligned}
C F & =\frac{\sum \mathrm{kWh} \text { produksi bruto per bulan }}{\sum \text { kapasitas terpasang x periode }} \times 100 \% \\
& =\frac{38086 \mathrm{MWh}}{63 \mathrm{MW} \times 744} \times 100 \% \\
& =81,3 \%
\end{aligned}
$$

Unit 2:

Produksi Listrik Bruto $=40095 \mathrm{MWh}$

Kapasitas Terpasang $=63 \mathrm{MW}$

Periode $=744 \mathrm{Jam}$ 
78 Muas M, Syaharuddin R, Arwin S, Alfian N. Perancangan Belt Konveyor Kapasitas 25 TPH (Studi Kasus : PT. Bumi Mineral Sulawesi)

$$
\begin{aligned}
& \text { Sehingga: } \\
& \begin{aligned}
\text { CF } & =\frac{\sum \mathrm{kWh} \text { produksi bruto per bulan }}{\sum_{\text {kapasitas terpasang x periode }}} \times 100 \% \\
& =\frac{40095 \mathrm{MWh}}{63 \mathrm{MW} \times 744} \\
& =85,5 \%
\end{aligned}
\end{aligned}
$$

Perhitungan yang sama untuk mendapatkan Capacity Factor pada semua data pengamatan, maka didapatkan rekap pencapaian Capacity Factor (CF) untuk unit 1 dan 2 PLTA Bakaru selama kurun waktu Januari 2015 sampai dengan Desember 2016 adalah nilai Capacity Factor yang berbeda untuk tiap bulannya masing-masing unit pembangkit, hal ini dikarenakan pengaruh perubahan musim serta debit inflow. Sehingga pemakaian air (discharge) dan produksi daya listrik untuk masing-masing unit

\begin{tabular}{|c|c|c|c|c|c|c|c|c|c|c|c|}
\hline \multirow[b]{2}{*}{ No } & \multirow[b]{2}{*}{ Bulan } & \multirow{2}{*}{$\begin{array}{c}\text { PERIODE } \\
\text { HOURS } \\
\text { (PH) } \\
\text { (Jam) } \\
\end{array}$} & \multicolumn{3}{|c|}{ DMN (MW) } & \multicolumn{3}{|c|}{ PRODUKSI BRUTO (MWh) } & \multicolumn{3}{|c|}{ CF ( $\%)$} \\
\hline & & & $\begin{array}{c}\text { UNIT } \\
1\end{array}$ & $\begin{array}{c}\text { UNIT } \\
2\end{array}$ & TOTAL & UNIT 1 & UNIT 2 & TOTAL & $\begin{array}{c}\text { UNIT } \\
1 \\
\end{array}$ & $\begin{array}{c}\text { UNIT } \\
\mathbf{2} \\
\end{array}$ & rata-rata \\
\hline 1 & jan & 744 & 63 & 63 & 126 & 38086 & 40095 & 78181 & 81,3 & 85,5 & 83,4 \\
\hline 2 & feb & 672 & 63 & 63 & 126 & 30206 & 27835 & 58040 & 71,3 & 65,7 & 68,5 \\
\hline 3 & mar & 744 & 63 & 63 & 126 & 41112 & 44402 & 85515 & 87,7 & 94,7 & 91,2 \\
\hline 4 & apr & 720 & 63 & 63 & 126 & 45481 & 45405 & 90886 & 100 & 100 & 100 \\
\hline 5 & mei & 744 & 63 & 63 & 126 & 46417 & 46890 & 93308 & 99 & 100 & 99,5 \\
\hline 6 & jun & 720 & 63 & 63 & 126 & 39787 & 43741 & 83528 & 87,7 & 96,4 & 92,1 \\
\hline 7 & jul & 744 & 63 & 63 & 126 & 20945 & 28945 & 49890 & 44,7 & 61,8 & 53,2 \\
\hline 8 & agu & 744 & 63 & 63 & 126 & 9930 & 26065 & 35995 & 21,2 & 55,6 & 38,4 \\
\hline 9 & sep & 720 & 63 & 63 & 126 & 11264 & 13198 & 24462 & 24,8 & 29,1 & 27,0 \\
\hline 10 & okt & 744 & 63 & 63 & 126 & 6073 & 16092 & 22164 & 13,0 & 34,3 & 23,6 \\
\hline 11 & nov & 720 & 63 & 63 & 126 & 8685 & 25654 & 34339 & 19,1 & 56,6 & 37,9 \\
\hline 12 & des & 744 & 63 & 63 & 126 & 23495 & 34935 & 58430 & 50,1 & 74,5 & 62,3 \\
\hline \multicolumn{9}{|c|}{ RATA-RATA CF TAHUN 2015} & 58,4 & 71,2 & 64,8 \\
\hline
\end{tabular}
juga berbeda. Hasil perhitungan Capacity Factor (CF) untuk masing-masing turbin dapat dilihat pada Tabel 5.

Tabel 5. Data pencapaian Capaccity Factor (CF) PLTA Bakaru tahun 2015.

Berdasarkan Tabel 5 pencapaian nilai CF tertinggi pada bulan April yaitu 100\%, dengan produksi yang dihasilkan unit $145.481 \mathrm{MWh}$ dan unit $245.404 \mathrm{MWh}$. Pencapaian hasil nilai tersebut dapat tercapai karena unit 1 dan unit 2 beroperasi pada beban maksimum secara konstan tanpa ada gangguan peralatan. Nilai rata-rata Capacity Factor sebesar 64,8 \%, angka tersebut membuktikan bahwa unit pembangkitan PLTA Bakaru dalam kondisi handal dalam memproduksi energi pada tahun 2015. Untuk lebih detailnya, berikut data dalam bentuk grafik nilai CF masing-masing unit di setiap bulannya dapat dilihat pada Gambar 4. 


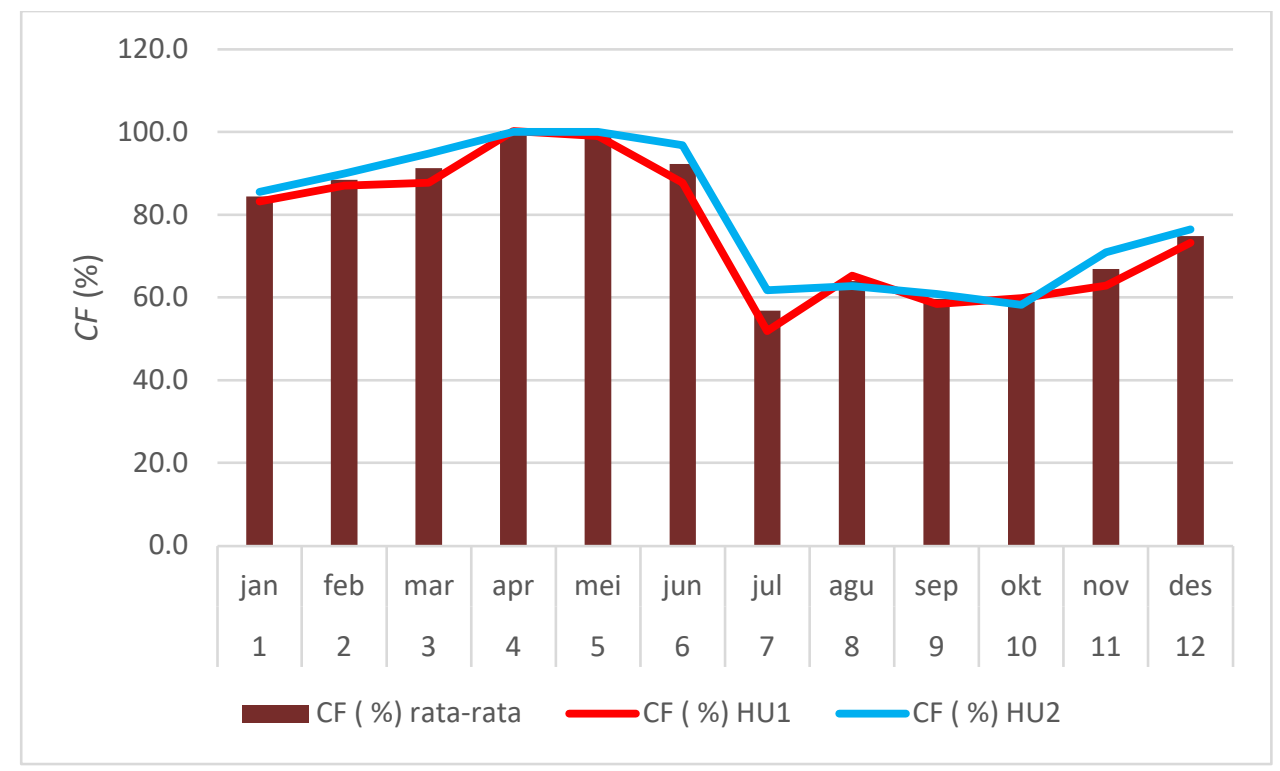

Gambar 4. Grafik Capacity Factor terhadap waktu

Berdasarkan Gambar 4 Pencapaian nilai Capacity Factor tertinggi unit 1 dan unit 2 sebesar 100\% di bulan April. Hal ini membuktikan bahwa PLTA Bakaru dalam kondisi yang prima dalam memproduksi energi di tahun 2015.

\section{KESIMPULAN}

Berdasarkan hasil analisa dan pengolahan data maka dapat disimpulkan bahwa:

1) Sistem monitoring debit inflow untuk operasi harian pembangkit dapat mengoptimalkan rencana operasi harian berdasarkan perubahan debit inflow yang masuk pada bendungan PLTA Bakaru.

2) Mengurangi range start stop pembangkit sehingga Lifetime peralatan pembangkit akan tercapai.

3) Nilai Capacity Factor (CF) dapat ditingkatkan dengan mengoptimalkan jam kerja operasi pembangkit.

\section{DAFTAR PUSTAKA}

[1] The New JEC., "Gate discharge and Reservoir Storage reference table Hydro Electric Power Project." PT.PLN Persero: Bakaru, 1990.

[2] The New JEC. "Operation and Maintenance Manual for Generating Equipment Vol I, II, III Hydro Electric Power Project.” PT.PLN Persero: Bakaru, 1990.

[3] W. Winasis, H. Prasetijo, and G. A. Setia, "Optimalisasi Jangka Menengah PLTA Memperhatikan Ketersediaan Air Menggunakan Linear Programming," J. Nas. Tek. Elektro dan Teknol. Inf., vol. 3, no. 2, pp. 152-156, 2014.

[4] A. Cateni, L. Magri, and G. Grego, "Optimization of Hydro Power Plants PerformanceImportance of rehabilitation and maintenance in particular for the runner profiles," in Proc, 2008, vol. 7.

[5] McMahon, T.A. McMahon, and G.M. Russel "Reservoir Capacity And Yield" Amsterdam: Elsevier Scientific Publishing Company, 1978. 